\title{
Effect of Human Chorionic Gonadotropin on Gastric Emptying in Female Rats: Is It a Direct Effect or by Induced Hyperthyroidism?
}

\author{
EMAN R. ABOZAID, M.D.* and NAGLAA A. AHMED, M.D.*,** \\ The Department of Physiology, Faculty of Medicine, Zagazig University, Egypt* and On Sabbatical Leave to Physiology \\ Department, Faculty of Medicine, Nagran University, KSA**
}

\begin{abstract}
Background: Delayed gastric emptying with prolongation of gastrointestinal transit time resulting in nausea and vomiting of pregnancy (NVP) which is the most common disorder during the first trimester of pregnancy with significant morbidity and adverse birth outcomes, few percentage of women develop a severe form of NVP called hyperemesis gravidarum (HG). The mechanism of NVP remains unclear with wide controversy, Several observational studies have suggested that NVP are related to the high levels of human chorionic gonadotropin (hCG), others relate it to hCG induced transient hyperthyroidism that commonly occur during pregnancy, these studies did not ascertain the possible relationship and mechanism either which hormone is the direct responsible?
\end{abstract}

Aim of the Study: To investigate the effect of hCG treatment and thyroid hormone changes on gastric transit in hCG treated female rats.

Material and Methods: This study was done on 18 female Wister albino rats, were divided to 3 groups $(n=6)$ : Control group (I) treated with saline, hCG treated group (II), and hCG + Methimazole treated group (III). After 2 weeks, at the end of the study, in all group, serum levels of Thyriod stimulating hormone (TSH), free (thyroxine) T4, hCG, estrogen and progesterone were estimated and gastric empting time was calculated. Groups comparison were done by applying one way analysis of variance (ANOVA) and the relationship between various parameters was evaluated by calculating coefficient of correlation, " $r$.

Results: Gastric emptying time was significantly decreased in both hCG treated groups and correlate negatively with hCG levels. Free serum T4 was significantly increased and TSH levels was significantly decreased in hCG treated group (II) in comparison to both control (I) and Methimazole treated (III) groups. Estrogen and progesterone levels showed no significant changes in both hCG treated groups when compared to control.

Conclusion: Our results are confirmative of the involvement of hCG in the pathogenesis of NVP and HG through a mechanism involving delaying gastric emptying time with no implication of hCG induced hyperthyroidism in this pathogenesis.

Correspondence to: Dr. Eman R. Abozaid, E-Mail: eman.zaher2005@gmail.com
Key Words: Nausea and Vomiting of Pregnancy - Human chorionic gonadotropin.

\section{Introduction}

DELAY in gastric emptying time, is one of the most common disorder in pregnant female [1], Pregnant women with delayed gastric emptying suffer from nausea, vomiting, or abdominal distension during the course of pregnancy, mainly during the first trimester [2] . Nausea and Vomiting of Pregnancy (NVP) is a very common disorder reported in $70-80 \%$ of all pregnant female $[3,4,5]$. It peak between 9 and 16 weeks of gestation and generally resolve by 22 weeks gestation, the severity of symptoms for NVP range from mild to moderate nausea and vomiting to a severe form of NVP called hyperemesis gravidarum (HG), which may lead to adverse birth outcomes with significant maternal morbidity and mortality [6-11] .

Human chorionic gonadotropin (hCG), a hormone secreted by the placental trophoblast, it is suspected to be involved in NVP and HG pathology, as $\mathrm{hCG}$ concentrations rise rapidly during the first trimester and peak at 10-12 weeks of gestation [12,13] . In 1992, Goodwin et al. [14], reported that serum hCG concentrations are significantly increased in women with HG compared with female of comparable gestational age. Furthermore, hCG concentrations correlate with the severity of vomiting, those findings suggest that hCG may play a role in the pathogenesis of NVP and gastrointestinal transit.

Despite the numerous studies linking hCG to NVP and HG, the role of hCG in these pathologies is not clear, Research has offered conflicting data about the relationship between serum hCG levels and severity of symptoms of NVP [15] 
On the other hand, it was observed that hyperthyroidism was present in $70 \%$ of women with HG [16]. As hCG stimulates the thyroid gland by crossreacting with the alpha-subunit of TSH receptor [14]. This hCG effect leads to suppression in TSH and slightly elevation in free $\mathrm{T} 4$, this effect resolves spontaneously by the second trimester $[6,17,18]$ Moreover, Rodien et al. [19] suggested a direct relationship between hyperthyroidism and HG, as treatment of thyrotoxicosis led to improvement of vomiting.

In controversy, some studies assumed that estrogen and progesterone, that increased in pregnancy may be directly and indirectly involved in the pathogenesis of NVP [20,21,22], as they may be mediators of esophageal dysmotility in pregnancy as well as changes in gastric rhythmic activity that may contribute to NVP $[\mathbf{6 , 2 4 , 2 5}$. In addition, total estradiol are reported to be higher in female with HG [25,26], although other studies could not confirm these findings [15]. Moreover, it has been reported that stimulation with hCG increase serum concentrations of progesterone and estrogen in a mouse model [27].

It was found that estradiol treatment inhibits gastric emptying in Female rats $[\mathbf{2 8 , 2 9 , 3 0 ]}$. This study also demonstrated that estrogen and a combination of estrogen and progesterone inhibit gastric emptying, but progesterone alone enhances gastric emptying in female rats [31]. Furthermore, in male rats, low-dose progesterone has been reported to increase gastric emptying, while high-dose progesterone inhibits it [32].

Although the pathogenesis of NVP and HG remain unclear, it is likely to be multifactorial and that various endocrine, genetic, and gastrointestinal factors may be involved [33] .

\section{Material and Methods}

\section{Experimental animals:}

In the period from 1st of May 2018 to $30^{\text {th }}$ May 2018, this study was performed on 18 female albino rats in Faculty of Medicine, Zagazig University. Rats were 4-5 weeks old weighing 90-110gm and were obtained from the animal house of Faculty of Veterinary Medicine, Zagazig University. Animals were kept in clean wire cages at comfortable temperature with 12-hour light/dark cycles and with free access to food and water. All rats received care in accordance with the national health guidelines and the study protocol was approved by the Institutional Review Board and Ethics Committee of Faculty of Medicine, Zagazig University. After two weeks' acclimatization period, the animals were randomized into three main groups:

Animal grouping and drug treatment:

Control animals group (I):

Control animals $(n=6)$ : Control rats were intraperitonially injected with vehicle alone $(0.1 \mathrm{ml}$ saline).

\section{HCG treated group (II):}

$(n=6)$ : (To mimic the condition of pregnancy), each rat was subjected to a single daily dose of hCG (100IU). The H.C.G. is available in the market as Epiphasi 5000IU (Epico, Egypt).

The Ampoule/Vial Size: 5000IU hCG was diluted with a total of $5 \mathrm{~m} 1$ distilled water then each $1 \mathrm{ml}$ of the mixture was divided for ten rats. Injected intraperitoneally for 2 weeks [34] with some modification.

\section{HCG + Methimazole treated group (III):}

$(\mathrm{n}=6)$ : Each rat was subjected to a single daily dose of hCG (100IU) injected intraperitoneally for 2 weeks. In addition to Methimazole (antithyriod drug was given by minimal dose to antagonize effect of hCG on thyriod stimulation without causing hypothyriodism) added to drinking water [35] by dose of $10 \mathrm{mg} / \mathrm{dL}(0.01 \%)$ for 2 weeks in the form of carbimazole tablets each tablet contains $5 \mathrm{mg}$ Methimazole (Amoun Co. S.A.E., Cairo, Egypt).

At the end of the study period, all animals were anaesthetized, sacrificed by decapitation, blood was allowed to clot then centrifuged and serum was separated and kept frozen in dark containers till the time of analysis. In all group, serum levels of hCG, TSH, free T4, estrogen and progesterone were estimated and gastric emptying time was calculated.

\section{Measurement of gastric emptying time:}

According to [40], after fasting (18-20 hours) for food with free access to water, rats housed one per cage, then pre-weighed, $10 \mathrm{~g}$ pellet of rat chow for consumption. All rats had no food left in the cage before assessment of emptying. Collected spillage was weighed in order to accurately measure how much of the $10 \mathrm{~g}$ meal was consumed, each rat were treated by intraperitoneal injection of $\mathrm{hCG}$ $100 \mathrm{IU}$ at the same time of refeeding. The percentage of gastric emptying of the ingested meal was assessed 2 hours after the end of food exposure. Mice were killed by cervical dislocation followed by thoracotomy. The abdominal cavity was opened, the pylorus and cardia clamped and the stomach 
removed. The stomach was weighed, opened and the gastric content was washed out with tap water. The gastric wall was wiped dry and weighed. The amount of food $(\mathrm{g})$ contained in the stomach was calculated as the difference between the total weight of the stomach with content and the weight of the stomach wall after the content was removed. The solid food ingested by each animal before any treatment was determined by the difference between the food weight before and $2 \mathrm{~h}$ after the feeding period. The percentage of gastric emptying for the $2 \mathrm{~h}$ period was calculated according to the equation: Percentage of gastric emptying $(\%)=$

$[1$ - Gastric content (g)/ Food intake (g)] x 100

\section{Biochemical measurements:}

Determination of Serum hCG levels: By ADVIA Centaur immunoassay System (Siemens), according to Wilde et al. [36].

Determination of serum T4 and TSH level: By radioimmunoassay according to Lethotaty et al. [37] and Cardosi et al. [38] respectively Using Elecsys D-68298 Mannheim, Germany kits (T4) and Chemiluminescence immunoassay Biotech TSH CLIA kits (Jei Daniel Biotech Corp. Inc., France).

Determination of serum estrogen and progesterone levels: According to Tietz [39] using rat kits: BC-1031, BC-1029, BC-1111, BC-1113 and BC1115, respectively, BioCheck Inc 323 Vintage Park Dr. Foster City, CA 94404.

Statistical analysis: Values are expressed as mean \pm standard deviation (SD). Means were compared by using one way analysis of variance (ANOVA) with LSD post hoc test. For bivariate correlations Pearson correlation coefficient " $r$ " was used. Statistical analysis was performed using the IBM Statistical Package for the Social Sciences (IBMSPSS), version 24 (SPSS Inc., Chicago, IL, United
States) for Windows. $p$-value $<0.05$ was regarded as significant.

\section{Results}

Effect of hCG treatment on gastric emptying in female rats:

Table (1) shows a comparison of gastric emptying in the 3 groups of rats. Gastric emptying was significantly decreased in both hCG treated (Group II) and hCG + Methimazole treated group (Group III) in comparison to control rats $(p<0.01)$. In addition, serum hCG levels showed significant negative correlation with gastric emptying $(p<0.01)$ in both hCG treated and hCG + Methimazole treated groups as shown in Table (2).

Effect of treatment with $h C G+$ low dose Methimazole on gastric emptying in female rats:

As shown in Table (1), significant decrease in gastric emptying in hCG + Methimazole treated group (Group III) in comparison to control rats $(p<0.01)$. However, there was no significant difference in gastric emptying time between $\mathrm{hCG}$ treated group and $\mathrm{hCG}+$ methimazol treated group $(p>0.05)$.

Effect of hCG treatment on free serum $T_{4}$ levels and serum TSH in hCG treated group (group II) in comparison to control rats:

As shown in Table (1), hCG treatment in group II resulted in an significant increase in free serum $\mathrm{T}_{4}$ concentration when compared with control $(p<0.05)$, on the other hand a significant decrease in TSH concentration when compared with controls $(p<0.05)$. I addition, serum hCG showed significant positive correlation with free serum $\mathrm{T}_{4}(p<0.05)$ while significant negative correlation with TSH $(p<0.05)$ as shown in Table (2).

Table (1): Show serum levels of hCG (mIU/ml), free T4 (ng/dl) and TSH ( IU/mL), estrogen (pg/ml), progesterone (ng/ml) and gastric emptying time $(\%)$ in the three studied groups.

\begin{tabular}{|c|c|c|c|c|c|c|}
\hline \multirow[b]{2}{*}{ Parameters } & \multirow[b]{2}{*}{$X \pm S D$} & \multirow{2}{*}{$\begin{array}{c}\begin{array}{c}\text { Control } \\
\text { (group I) }\end{array} \\
X \pm \text { SD }\end{array}$} & \multicolumn{2}{|c|}{$\begin{array}{l}\text { HCG treated group } \\
\quad(\text { Group II) }\end{array}$} & \multicolumn{2}{|c|}{$\begin{array}{c}\mathrm{HCG}+\text { Methimazole treated } \\
\text { group (Group III) }\end{array}$} \\
\hline & & & PVS group I & $X \pm S D$ & PVS group I & PVS group II \\
\hline $\mathrm{HCG}(\mathrm{ng} / \mathrm{mL})$ & $12.38 \pm 5.89$ & $7733.19 \pm 658.35$ & $<0.001 * *$ & $7684.9 \pm 465.46$ & $<0.001 * *$ & $>0.05$ \\
\hline Gastric empting time $\%$ & $79.3 \pm 7.99$ & $49.8 \pm 6.05$ & $<0.001 * *$ & $48.8 \pm 8.82$ & $<0.001 * *$ & $>0.05$ \\
\hline Free $\mathrm{T}_{4}(\mathrm{ng} / \mathrm{dL})$ & $1.7 \pm 0.19$ & $2.29 \pm 0.16$ & $<0.001 * *$ & $1.49 \pm 0.26$ & $>0.05$ & $<0.001 * *$ \\
\hline TSH ( UUmL) & $0.009 \pm 0.001$ & $0.003 \pm 0.001$ & $<0.01 *$ & $0.011 \pm 0.005$ & $>0.05$ & $<0.001 * *$ \\
\hline Estrogen $\mathrm{pg} / \mathrm{ml}$ & $35 \pm 4.6$ & $38.68 \pm 11.21$ & $>0.05$ & $36.35 \pm 9.67$ & $>0.05$ & $>0.05$ \\
\hline Progesterone $\mathrm{ng} / \mathrm{ml}$ & $16.1667 \pm 1.47$ & $17.57 \pm 1.65$ & $>0.05$ & $17.9 \pm 1.85$ & $>0.05$ & $>0.05$ \\
\hline
\end{tabular}

Data expressed as mean $\pm \mathrm{SD} . \quad p$-value is significant at $<0.05$.

*Significant. 
Effect of treatment with hCG + low dose Methimazole on free serum t4 levels and serum TSH:

Table (1) show that in hCG + Methimazole treated group (group III) there was significant decrease in free serum $t 4$, while significant increase in TSH concentration when compared with $\mathrm{hCG}$ treated group (Group II) $(p<0.05)$, but no significant change when compared with control $(p>0.05)$.

Effect of hCG on serum estradiol and progesterone in comparison to control rats:

As shown in Table (1), hCG treatment in both group insignificantly increase serum estradiol and progesterone levels $(p>0.05)$.

Table (2): Correlation between serum hCG levels and levels of TSH, free T4, Estrogen, progesterone and gastric emptying time in both hCG treated and hCG + Methimazole treated groups.

\begin{tabular}{|c|c|c|c|c|}
\hline & \multicolumn{2}{|c|}{$\begin{array}{l}\text { HCG treated } \\
\text { group } \\
\text { (Group II) }\end{array}$} & \multicolumn{2}{|c|}{$\begin{array}{c}\text { HCG + } \\
\text { Methimazole } \\
\text { treated group } \\
\text { (Group III) }\end{array}$} \\
\hline & $r$ & $p$ & $r$ & $p$ \\
\hline TSH ( IUml) & $-0.882 *$ & $<0.05$ & -0.577 & $>0.05$ \\
\hline T4 (ng/dl) & $0.781 *$ & $<0.05$ & 0.225 & $>0.05$ \\
\hline Estrogen $\mathrm{pg} / \mathrm{ml}$ & -0.367 & $>0.05$ & 0.058 & $>0.05$ \\
\hline progesterone $\mathrm{ng} / \mathrm{ml}$ & 0.316 & $>0.05$ & 0.372 & $>0.05$ \\
\hline Gastric empting time\% & $-0.932 * *$ & $<0.01$ & $-0.897 *$ & $<0.05$ \\
\hline
\end{tabular}

$r=$ Correlations with serum hCG levels of the same group. $p<0.05$ is significant.

*Significant correlation vs hCG level.

\section{Discussion}

In this study, we evaluate gastric emptying time as an indicator for NVP and HG, we depend in this concept on many studies that confirm that NVP pathogenesis is due to delay gastric emptying time $[1,2]$.

In the current study we showed that hCG treatment resulted in inhibition of gastric emptying in young female rats, hCG showed significant negative correlation with gastric empting.

Our result is supported by many studies that observed increase levels of hCG with onset of NVP or HG, Besides, hCG levels decline in a similar manner to the decline of the HG symptoms, moreover, nausea and vomiting are often worse in pregnant women with conditions associated with elevated hCG levels such as molar pregnancies, multiple gestations $[6,13,15,34,41,42]$.

On the other hand, Niemeijer et al. [43] did not find relationship between serum hCG in pregnant female and the occurrence and severity of nausea and vomiting.

These conflicting results about the role of hCG in NVP is based on reports suggesting that the increased levels of acidic hCG isoforms which appears to play a role in NVP [44]. These different isoforms of hCG are likely the result of genetic or epigenetic factors which may explain the differences in NVP incidence found in different populations [6]. In addition, hCG receptor mutations may explain some of the variability in the relationship between NVP and hCG [14].

Our result observed significant effect for hCG on thyroid stimulation in consistent with some observational studies on pregnant women that observed positive correlation between hCG and thyroid hormone levels with negative correlation with TSH with conclusion suggesting thyroid stimulating effect of beta hCG [45,46,47] .

As observed in our result gastric emptying delayed with hCG elevation in both groups with and without hyperthyroidism so we approved no role for thyroid hormone in delaying gastric empting so no contribution for transient gestational hyperthyroidism in NVP or HG.

On coincide with us $[48,49]$ observed no relationship between thyroid dysfunction and the severity of HG symptoms, moreover, treatment with propylthiouracilntithyriod does not alleviate the nausea and vomiting in HG patients and patients with primary hyperthyroidism rarely have vomiting [50], moreover, transient gestational hyperthyroidism does not affect pregnancy outcomes [16].

However, other results are suggestive of the involvement of thyroid in the pathogenesis of morning sickness and $\mathrm{HV}$ as they observed that thyroxin levels were significantly changed and the increase or decrease in their level correlated with the severity of symptoms [51,52].

In our study, decreased gastric emptying was seen in rats with normal levels of estrogen and progesterone as our finding showed no significant effect for hCG on estrogen and progesterone levels, as this model is not true pregnancy (no placenta), even though hCG was applied to mimic the first trimester in pregnancy, the present animal model does not completely mimic pregnant women, in whom hCG given for short duration and done on young rats with premature ovaries. But this model was suitable to study the effect of hCG on gastric emptying without interference of other hormones. 
Normal estrogen and progesterone levels exclude any effect for these two hormones on delay of gastric empting time in our study, this support our conclusion that hCG is the main responsible for this effect with the possible mechanism mentioned above.

Further studies are needed to clarify the contribution of hyper secretion of estrogen and progesterone on gastric emptying and gastric rhythmic activity in female rats.

On supporting of our finding, Seow et al. [34] showed that hCG inhibit gastric emptying in ovarectomized rat model and suggested that hCG could stimulate cholycystokinin hormone (CCK) release through binding with $\mathrm{hCG} / \mathrm{LH}$ receptors in the brain, neurons or small intestine, the inhibition of gastric emptying induced by hCG via a peripheral mechanism involving CCK hypersecretion and CCK1 receptor activation that may explain the gastric distension and NVP seen in women during the first trimester of pregnancy. However, further studies should be done to prove this relationship.

\section{Conclusion:}

This study showed that hCG treatment inhibit gastric emptying in female rats with no role for thyroid hormone, in addition to absence of any possible effect for estrogen and progesterone on gastric emptying suggesting that NVP mediated mainly by hCG and the gestational transient hyperthyroidism if present it is just association and not a cause for NVP or HG.

Further studies are needed to confirm mechanisms behind hCG effect on gastric emptying.

\section{References}

1- CHILOIRO M., DARCONZA G., PICCIOLI E., De CARNE M., CLEMENTE C. and RIEZZO G.: Gastric emptying and orocecal transit time in pregnancy. Journal of Gastroenterology, 36: 538-543, 2001.

2- JARNFELT-SAMSIOE A., SAMSIOE G. and VELINDER G.M.: Nausea and vomiting in pregnancy a contribution to its epidemiology. Gynecol Obstet Invest., 16: 221-229, 1983.

3- FLAXMAN S.M. and SHERMAN P.W.: Morning sickness: A mechanism for protecting mother and embryo. Q. Rev. Biol., 75: 113-148, 2000.

4- LACROIX R., EASON E. and MELZACK R.: Nausea and vomiting during pregnancy: A prospective study of its frequency, intensity, and patterns of change. Am. J. Obstet. Gynecol., 182: 931-937, 2000.

5- PEPPER G.V. and CRAIG ROBERTS S.: Rates of nausea and vomiting in pregnancy and dietary characteristics across populations. Proc. Biol. Sci., 273: 2675-2679, 2006.
6- LEE N.M. and SAHA S.: Nausea and vomiting of pregnancy. Gastroenterol. Clin. North Am., 40: 309-334. vii., 2011.

7- ZUR E.: Nausea and vomiting in pregnancy: A review of the pathology and compounding opportunities. Int. J. Pharm. Compd., 17: 113-123, 2013.

8- KANTOR S., PRAKASH S., CHANDWANI J., GOKHALE A., SARMA K. and ALBAHRANI M.J.: Wernicke's encephalopathy following hyperemesis gravidarum. Indian J. Crit. Care Med., 18: 164-166, 2014.

9- KNIGHT M., KENYON S., BROCKLEHURST P., NEILSON J., SHAKESPEARE J. and KURINCZUK J.J.K.: Saving Lives, Improving Mothers' Care Lessons learned to inform future maternity care from the UK and Ireland Confidential Enquiries into Maternal Deaths and Morbidity 2009-12. University of Oxford, Oxford, National Perinatal Epidemiology Unit, 2014.

10- MacGIBBON K.W., FEJZO M.S. and MULLIN P.M. Mortality Secondary to Hyperemesis Gravidarum: A Case Report. Womens Health Gynecol., 1: 7, 2015.

11- World-Health-Organization. International statistical classification of diseases and related health problems. Geneva: 10th revision, 2016.

12- SOULES M.R., HUGHES C.L. Jr., GARCIA J.A., LIVENGOOD C.H., PRYSTOWSKY M.R. and ALEXAN DER E. 3rd.: Nausea and vomiting of pregnancy: Role of human chorionic gonadotropin and 17 -hydroxyprogesterone. Obstet. Gynecol., 55: 696-700, 1980.

13- PATIL C.L., ABRAMS E.T., STEINMETZ A.R. and YOUNG S.L.: Appetite sensations and nausea and vomiting in pregnancy: An overview of the explanations. Ecol. Food Nutr., 51: 394-417, 2012.

14- GOODWIN T.M., MONTORO M., MESTMAN J.H., PEKARY A.E. and HERSHMAN J.M.: The role of chorionic gonadotropin in transient hyperthyroidism of hyperemesis gravidarum. J. Clin. Endocrinol. Metab., 75: 1333-1337, 1992.

15- VERBERG M.F., GILLOTT D.J., AL-FARDAN N. and GRUDZINSKAS J.G.: Hyperemesis gravidarum, a literature review. Hum Reprod Update, 11: 527-539, 2005.

16- SUN S., QIU X. and ZHOU J.: Clinical analysis of 65 cases of hyperemesis gravidarum with gestational transient thyrotoxicosis. J. Obstet. Gynaecol. Res., 40: 1567-1572, 2014.

17- GLINOER D. and SPENCER C.A.: Serum TSH determinations in pregnancy: How, when and why? Nat. Rev. Endocrinol., 6: 526-529, 2010.

18- NAZARPOUR S., RAMEZANI TEHRANI F., SIMBAR M. and AZIZI F.: Thyroid dysfunction and pregnancy outcomes. Iran J. Reprod Med., 13: 387-396, 2015.

19- RODIEN P., JORDAN N., LEFEVRE A., ROYER J., VASSEUR C., SAVAGNER F., BOURDELOT A. and ROHMER V.: Abnormal stimulation of the thyrotrophin receptor during gestation. Hum. Reprod Update, 10: 95 105, 2004

20- LAGIOU P., TAMIMI R., MUCCI L.A., TRICHOPOULOS D., ADAMI H.O. and HSIEH C.C.: Nausea and vomiting in pregnancy in relation to prolactin, estrogens, and progesterone: A prospective study. Obstet. Gynecol., 101: 639-644, 2003. 
21- LADYMAN S.R. and GRATTAN D.R.: Region-specific reduction in leptin-induced phosphorylation of signal transducer and activator of transcription-3 (STAT3) in the rat hypothalamus is associated with leptin resistance during pregnancy. Endocrinology, 145: 3704-3711, 2004.

22- LADYMAN S.R., SAPSFORD T.J. and GRATTAN D.R.: Loss of acute satiety response to cholecystokinin in pregnant rats. J. Neuroendocrinol., 23: 1091-1098, 2011.

23- RICHTER J.E.: Review article: The management of heartburn in pregnancy. Aliment Pharmacol. Ther., 22: 749-757, 2005.

24- KOCH K.L. and FRISSORA C.L.: Nausea and vomiting during pregnancy. Gastroenterol. Clin. North Am., 32: 201-234. Vi, 2003.

25- DEPUE R.H., BERNSTEIN L., ROSS R.K., JUDD H.L. and HENDERSON B.E.: Hyperemesis gravidarum in relation to estradiol levels, pregnancy outcome, and other maternal factors: A seroepidemiologic study. Am. J. Obstet. Gynecol., 156: 1137-1141, 1987.

26- YONEYAMA Y., SUZUKI S., SAWA R. and ARAKI T.: Plasma adenosine concentrations increase in women with hyperemesis gravidarum. Clin. Chim. Acta., 342: 99-103, 2004.

27- EZOE K., DAIKOKU T., YABUUCHI A., MURATA N., KAWANO H., ABE T., OKUNO T., KOBAYASHI T. and KATO K.: Ovarian stimulation using human chorionic gonadotrophin impairs blastocyst implantation and decidualization by altering ovarian hormone levels and downstream signaling in mice. Mol. Hum. Reprod., 20: 11011116, 2014.

28- KIMURA M., AMINO N., TAMAKI H., ITO E., MITSUDA N. and MIYAI K.: "Gestational thyrotoxicosis and hyperemesis gravidarum: Possible role of hCG with higher stimulating activity", Clinical Endocrinology, Vol. 38, No. 4. pp. 345-350, 1993.

29- WU C.L., HUNG C.R., CHANG F.Y., PAU K.Y. and WANG P.S.: Involvement of cholecystokinin receptor in the inhibition of gastrointestinal motility by estradiol in ovariectomized rats. Scandinavian Journal of Gastroenterology, 37: 1133-1139, 2002.

30- WU C.L., DOONG M.L. and WANG P.S.: Involvement of cholecystokinin receptor in the inhibition of gastrointestinal motility by oxytocin in ovariectomized rats. European Journal of Pharmacology, 580: 407-415, 2008.

31- CHEN T.S., DOONG M.L., CHANG F.Y., LEE S.D. and WANG P.S.: Effects of sex steroid hormones on gastric emptying and gastrointestinal transit in rats. American Journal of Physiology, 268: G171-G176, 1995.

32- LIU C.Y., CHEN L.B., LIU P.Y., XIE D.P. and WANG P.S.: Effects of progesterone on gastric emptying and intestinal transit in male rats. World Journal of Gastroenterology, 8: 338-341, 2002.

33- GAZMARARIAN J.A., PETERSEN R., JAMIESON D.J., SCHILD L., ADAMS M.M., DESHPANDE A.D. and FRANKS A.L.: Hospitalizations during pregnancy among managed care enrollees. Obstet. Gynecol., 100: 94-100, 2002.

34- SEOW KOK-MIN, LEE JYUN-LIN, DOONG MINGLUEN, HUANG SENG-WONG, HWANG JIANNLOUNG and HUANG: "Human chorionic gonadotropin regulates gastric emptying in ovariectomized rats". The Journal of endocrinology, Vol. 216, No. 3. pp. 307-14, 2013.

35- KOKKINOS A., MOUROUZIS I., KYRIAKI D., PANTOS C., KATSILAMBROS N. and COKKINOS D.V.: Possible implications of leptin, adiponectin and ghrelin in the regulation of energy homeostasis by thyroid hormone. Endocrine, 32: 30-32, 2007.

36- WILDE C., HILARY ORR A. and BAGSHAWE K.D.: A Radioimmunoassay for Human Chorionic Gonadotrophin Nature, Vol. 205: 191-192, 1965.

37- LETHOTAY D., WIGHT C., SETTMAN H. and SANGHVIL L.: Free thyroxine: Direct, indirect, use in nonthyroidal diseases. Clin. Chem., 28: 1862-1829, 1982.

38- CARDOSI M.F., BIRCH S.W., SMITH B.M. and JOHANNSSON A.: An enzyme-amplified electrochemical immunoassay for thyrotropin. Electroanalysis, 1: 297-304, 1989.

39- TIETZ N.W.: Clinical Guide to Laboratory Tests, ${ }^{3 \mathrm{rd}}$ Ed., W.B. Saunders Company, Philadelphia, 509-580, 1995.

40- MARTÍNEZ V., WANG L., RIVIER J., GRIGORIADIS D. and TACHÉ Y.: "Central CRF, urocortins and stress increase colonic transit via CRF1receptors while activation of CRF2 receptors delays gastric transit in mice", J. Physiol., Vol. 556, No. 1, pp. 221-234, 2004.

41- NIEBYL J.R.: Clinical practice. Nausea and vomiting in pregnancy. N. Engl. J. Med., 363: 1544-1550, 2010.

42- SANU O. and LAMONT R.F.: Hyperemesis gravidarum: Pathogenesis and the use of antiemetic agents. Expert Opin. Pharmacother, 12: 737-748, 2011.

43- NIEMEIJER M.N., GROOTEN I.J., VOS N., BAIS J.M., VAN DER POST J.A., MOL B.W., ROSEBOOM T.J., LEEFLANG M.M. and PAINTER R.C.: Diagnostic markers for hyperemesis gravidarum: A systematic review and metaanalysis. Am. J. Obstet. Gynecol., 211: 150 e151115, 2014.

44- JORDAN V., GREBE S.K., COOKE R.R., FORD H.C., LARSEN P.D., STONE P.R. and SALMOND C.E.: Acidic isoforms of chorionic gonadotrophin in European and Samoan women are associated with hyperemesis gravidarum and may be thyrotrophic. Clin. Endocrinol. (Oxf), 50: 619-627, 1999.

45- VIRMANI S., SRINIVAS S.B., BHAT R., RAO R. and KUDVA R.: "Transient thyrotoxicosis in molar pregnancy," Journal of Clinical and Diagnostic Research, Vol. 11, No. 7. pp. QD01-QD02, 2017.

46- HERSHMAN J.M.: "Human chorionic gonadotropin and the thyroid: hyperemesis gravidarum and trophoblastic tumors.," Thyroid: Official journal of the American Thyroid Association, Vol. 9, No. 7. pp. 653-7, 1999.

47- TALBOT J.A., LAMBERT A., ANOBILE C.J., MCLOUGHLIN J.D., PRICE A., WEETMAN A.P. and ROBERTSON W.R.: "The nature of human chorionic gonadotrophin glycoforms in gestational thyrotoxicosis", Clinical Endocrinology, Vol. 55, No. 1. pp. 33-39, 2001.

48- KIRSHON B., LEE W. and COTTON D.B.: Prompt resolution of hyperthyroidism and hyperemesis gravidarum after delivery. Obstet. Gynecol., 71: 1032-1034, 1988. 
49- EVANS A.J., LI T.C., SELBY C. and JEFFCOATE W.J.: Morning sickness and thyroid function. Br. J. Obstet. Gynaecol., 93: 520-522, 1986.

50- ELIAKIM R., ABULAFIA O. and SHERER D.M.: Hyperemesis gravidarum: A current review. Am. J. Perinatol., 17: $207-218,2000$
51- TAREEN A.K., BASEER A., JAFFRY H.F. and SHAFIQ M.: "Thyroid Hormone in Hyperemesis Gravidarum", Journal of Obstetrics \& Gynaecology, Vol. 21, No. 5. 1995.

52- MORI M., AMINO N., TAMAKI H. and MIYAI K. "Morning sickness and thyroid function in normal pregnancy”, Obstetrics \& Gynaecol., 72: 355-9, 1988.

\section{تأثير هرمون الغدد التناسلية المشيمية البشرى ألمعري

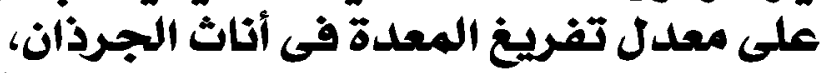

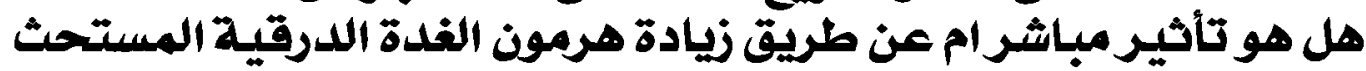

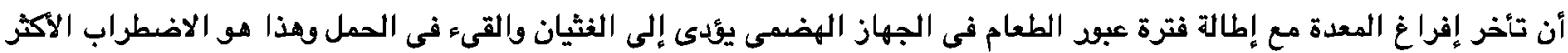

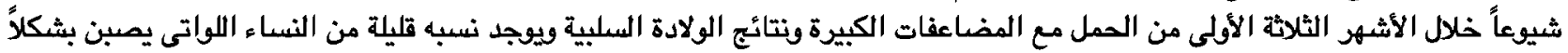

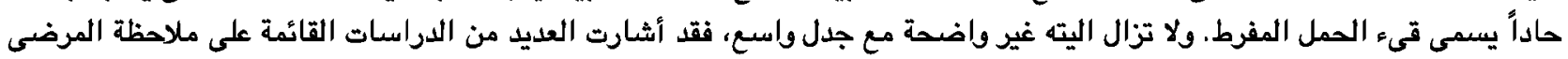

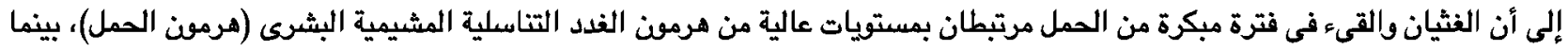

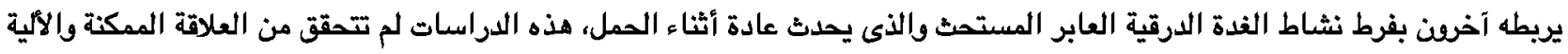

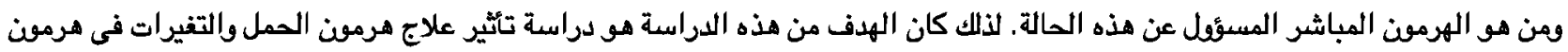
الغدة الدرقية على فترة العبود المعدية فى أناث الجرذان اللواتى يتعرضن للحقن بهرمون الحمل.

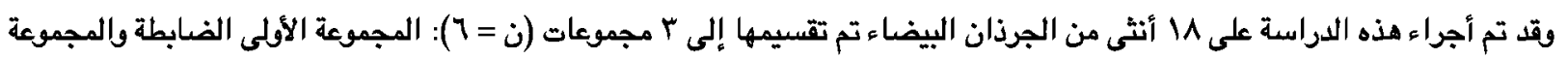

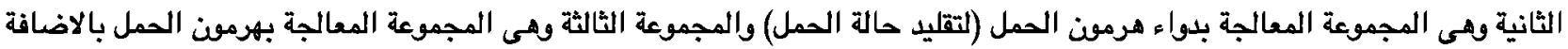
لعقار مضاد لهرمن الغدة الدرقية (الميثيمانول).

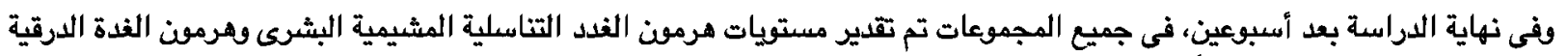

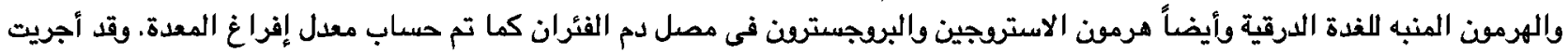

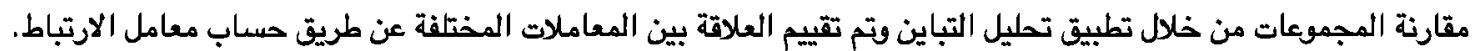

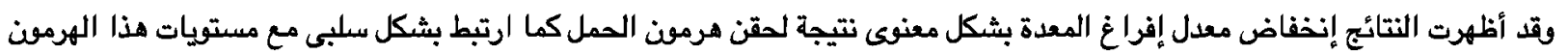

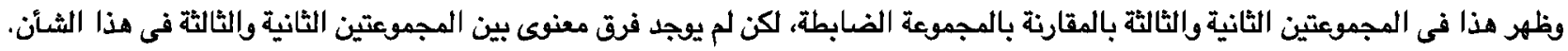

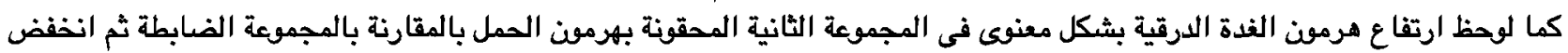

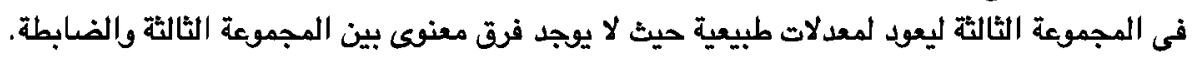

الكن لم تظهر مستويات هرمون الاستروجين والبروجستيرون أى تغيرات معنوية فى كل من المجموعات الثانية والثالثة بالمقارنة بالضابطة.

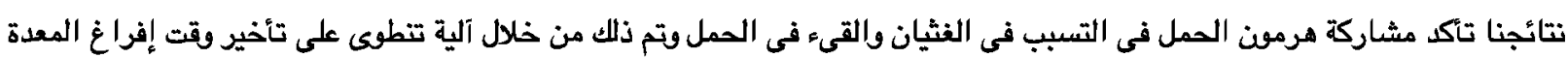
دون أى توط لهرمون الغدة الدرقية المرتقع الناتج عن فرط نشاط التئ الغدة الدرقية العابر أثناء الممل. كما استبعدت هذه الدراسة أى دور لهرمونى الاستروجين والبرجستيرن على معدل تفريغ المعدة في أناث الجرذان. 